\title{
Changes in bioavailability and tissue distribution of zinc caused by magnesium deficiency in rats
}

\author{
BY ELENA PLANELLS ${ }^{1}$, PILAR ARANDA ${ }^{1}$, ANA LERMA² AND \\ JUAN LLOPIS ${ }^{1 *}$ \\ ${ }^{1}$ Institute of Nutrition and Food Technology and ${ }^{2}$ Department of Physiology, University of \\ Granada, E-18071 Granada, Spain
}

(Received 7 June 1993 - Revised 26 November 1993 - Accepted 3 December 1993)

\begin{abstract}
The effect of a $\mathrm{Mg}$-deficient diet (200 $\mathrm{mg} \mathrm{Mg} / \mathrm{kg}$ feed) on the bioavailability of dietary $\mathrm{Zn}$ and the concentration of this cation in plasma, whole blood, skeletal muscle, kidney, heart and brain of Wistar rats was studied after 7, 35, 42, 49, 56, 63 and $70 \mathrm{~d}$. $\mathrm{Mg}$ deficiency significantly decreased $\mathrm{Zn}$ in whole blood on day 42 of the experiment, but there was no significant change in plasma $\mathrm{Zn}$ throughout the $70 \mathrm{~d}$ study period. The $\mathrm{Mg}$-deficient diet significantly increased intestinal absorption of $\mathrm{Zn}, \mathrm{Zn}$ balance, and $\mathrm{Zn}$ concentration in femur and kidney, but decreased $\mathrm{Zn}$ concentration in the heart despite the increase in dry weight of this organ. No change was found in brain $\mathrm{Zn}$ concentration.
\end{abstract}

Magnesium: Zinc: Rat

$\mathrm{Mg}$ is known to be essential for the metabolism of several minerals. The signs and symptoms of $\mathrm{Mg}$ deficiency are due, in part, to complex alterations in electrolyte balance secondary to the $\mathrm{Mg}^{2+}$ deficit.

Little has been published on the relationship between $\mathrm{Mg}$ deficiency and $\mathrm{Zn}$. The effects of $\mathrm{Mg}$ deficiency on $\mathrm{Zn}$ contents in several tissues in the gestating rat and pups have been described (Hurley \& Swenerton, 1966; Hurley \& Cosens, 1976); however, these reports dealt mainly with the placental transfer of $\mathrm{Zn}$ and the congenital malformations arising from alterations in mineral content in the fetus. Subsequent studies (Momcilovic et al. 1975; Forbes et al. 1984) examined the bioavailability of $\mathrm{Zn}$ in diets supplying different amounts of $\mathrm{Ca}$, phytate and $\mathrm{Mg}$, and suggested a possible interaction between cations during intestinal transport and in bone. More recently, Yasui et al. 1991 noted that a diet low in $\mathrm{Ca}$ and $\mathrm{Mg}$ caused changes in the tissue distribution of $\mathrm{Zn}$; however, this study provided no information on the changes caused exclusively by $\mathrm{Mg}$ deficiency.

In addition to these findings, there is evidence from epidemiological studies that $\mathrm{Mg}$ intake in a large percentage (approximately 30 ) of the population in industrialized countries is below the recommended daily allowance, and that $\mathrm{Mg}$ deficiency, together with inadequate dietary habits, can lead to many disease states (Wester, 1987). Therefore, we designed the present study to elucidate the relationship between $\mathrm{Mg}$ and $\mathrm{Zn}$, and to determine whether the latter indirectly contributes to the development of deficiency-related symptoms. Our approach was to examine the degree to which a $\mathrm{Mg}$-deficient diet affects the bioavailability of dietary $\mathrm{Zn}$ and the distribution of this element in different tissues.

The present study forms part of an ongoing project aimed at characterizing the evolution of $\mathrm{Mg}$ deficiency in rats under the same experimental conditions: rats weighing $180 \mathrm{~g}$ were given, during $70 \mathrm{~d}$, a diet that supplied $50 \%$ of the $\mathrm{Mg}$ requirements for this species (Lerma et al. 1993). 


\section{MATERIALS AND METHODS}

\section{Animals and diets}

Recently-weaned Wistar rats consumed a standard commercial diet (Panlab, Barcelona, Spain) until they reached a body weight of $180 \mathrm{~g}$. Thereafter they were allowed ad lib. access to bidistilled water and a semi-synthetic diet deficient in $\mathrm{Mg}$. The diet contained $(\mathrm{g} / \mathrm{kg})$ : protein (casein) 140, DL-methionine 5, sucrose 344, maize starch 344, fibre (cellulose) 80 , olive oil 40, AIN-76 mineral mix (without magnesium oxide) 35, AIN-76 vitamin mix 10, choline bitartrate 2 . In all, these components provided $200 \mathrm{mg} \mathrm{Mg}, 53.2 \mathrm{mg} \mathrm{Zn}, 6200 \mathrm{mg}$ $\mathrm{Ca}$ and $4400 \mathrm{mg} \mathrm{P} / \mathrm{kg}$ feed, as well as $25 \mu \mathrm{g}$ cholecalciferol $/ \mathrm{kg}$ feed.

To study the development of $\mathrm{Mg}$ deficiency, ten deficient rats (five males, five females) were killed by decapitation on days $7,35,42,49,56,63$ and 70 . Blood was collected and centrifuged to separate plasma. The femur, kidney, and longissimus dorsi muscle were also removed on days $7,35,42,49,56,63$ and 70 ; the heart was removed for analysis on days 7,42 and 63 . During the last $7 \mathrm{~d}$ of each experimental period the faeces and urine were collected for subsequent analyses, and the amount of feed ingested was recorded.

The results were compared with those for a group of control rats fed on the same diet, except that the amount of $\mathrm{Mg}$ was adequate to supply their nutritional requirements ( $465 \mathrm{mg} / \mathrm{kg}$ feed). Control animals were allowed access ad lib. to the diet during the first 4 weeks. Thereafter, control males were pair-fed with the deficient male having the lowest intake $(11.3 \mathrm{~g})$ and females with the lowest female intake $(9.3 \mathrm{~g})$.

All animals were kept in individual metabolism cages in a well-ventilated, temperaturecontrolled room $\left(21 \pm 2^{\circ}\right)$ with a light-dark period of $12 \mathrm{~h}$.

We calculated biological indices apparent absorption (AA), as $[(I-F) / I] \times 100$, and balance, as $I-(F+U)$, where $I$ is intake, $F$ is faecal excretion, and $U$ is urinary excretion (Food and Agriculture Organization/World Health Organization, 1966).

Changes in brain $\mathrm{Zn}$ content were studied in a separate experiment. Male rats were given the same Mg-deficient diet, and were killed by decapitation on days 35, 49,63 and 70. The brains were immediately removed for analysis, and the results were compared with a group of rats fed on the control diet.

\section{Analytical methods}

Dry matter was determined as the material remaining after heating to $105 \pm 2^{\circ}$ until weight was stable. Ash was obtained by calcination of 1 or $2 \mathrm{~g}$ samples at $450^{\circ}$. $\mathrm{Zn}$ and $\mathrm{Mg}$ were determined by atomic absorption spectrophotometry of a sample that had been previously mineralized by calcination at $450^{\circ}$.

The resulting residues were extracted with $6 \mathrm{M}-\mathrm{HCl}$ solution, brought up to an appropriate volume, and spectrophotometrically compared against a set of standards. Determinations in plasma were also made by atomic absorption spectrophotometry in samples that were not previously ashed.

\section{Statistical analysis}

The experimental data were subjected to Student's $t$ test. Differences were verified at the $5 \%$ level. Differences between sexes were small and inconsistent relative to treatment effects, and the latter were analysed using pooled data from both sexes.

\section{RESULTS}

Under our experimental conditions a faecal $\mathrm{Zn}$ excretion was significantly lower in rats that consumed the $\mathrm{Mg}$-deficient diet than in control animals between days 28 and 70 . Urinary 


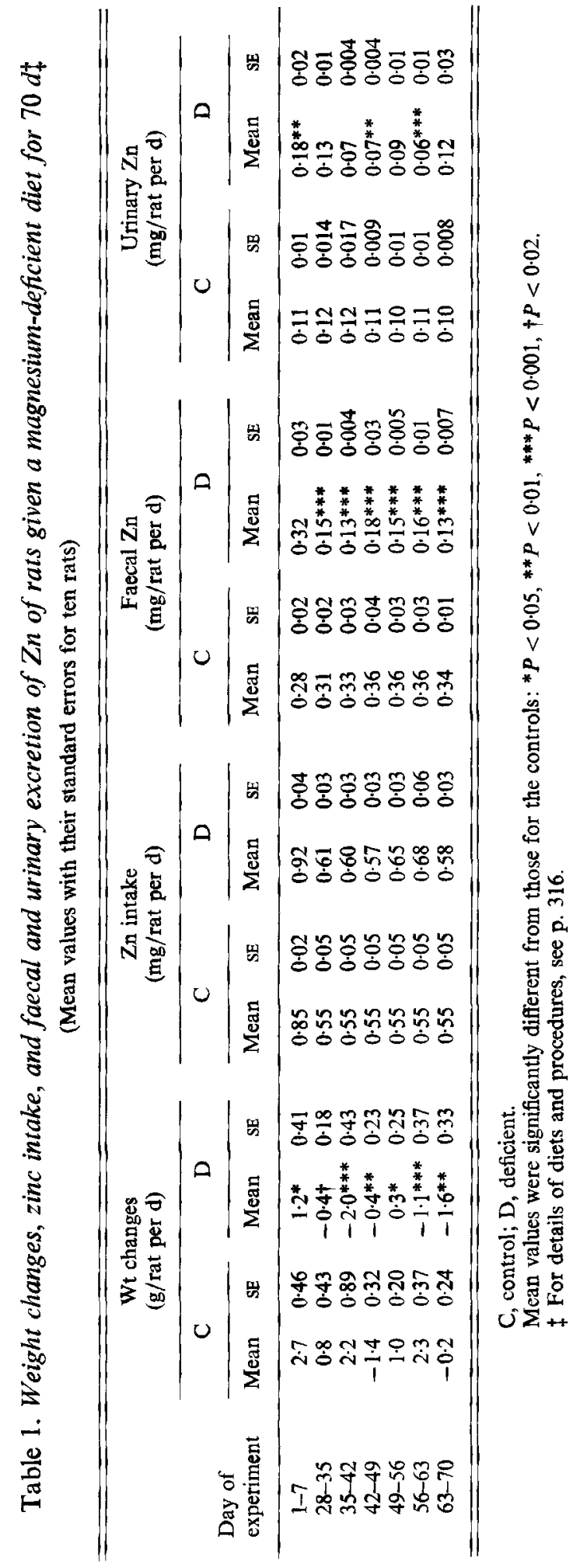




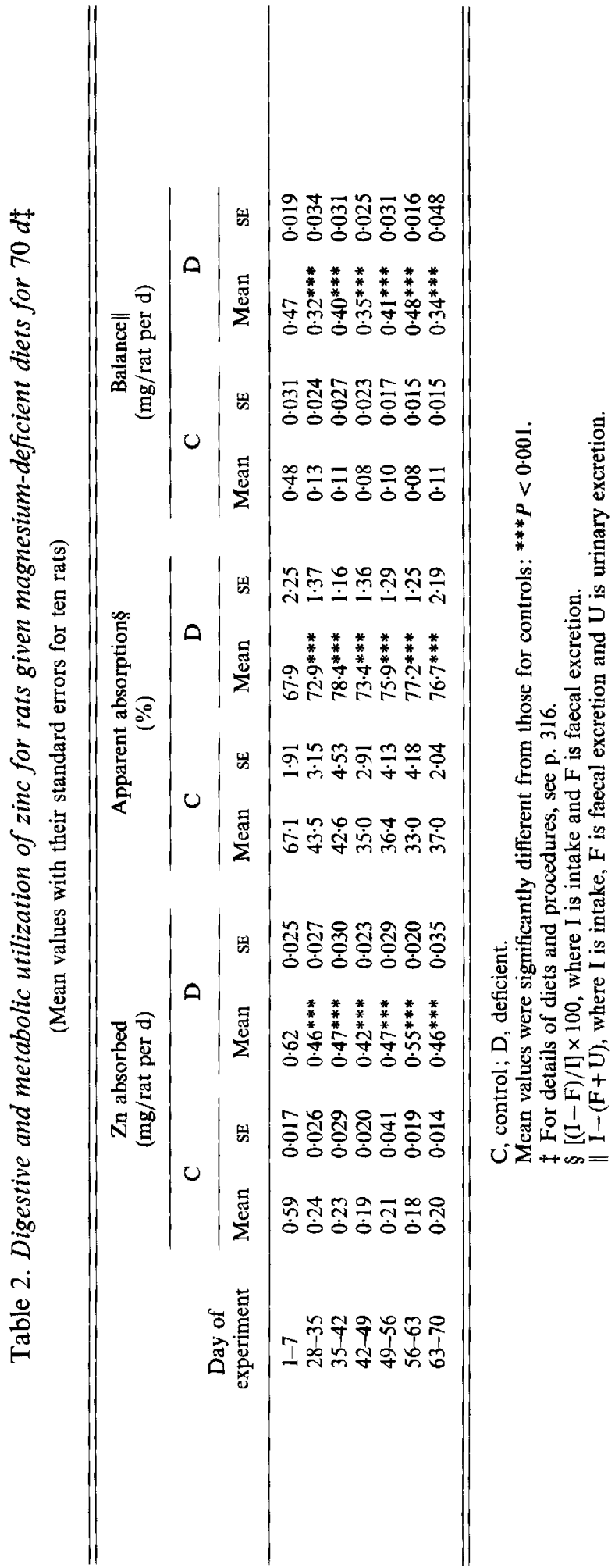




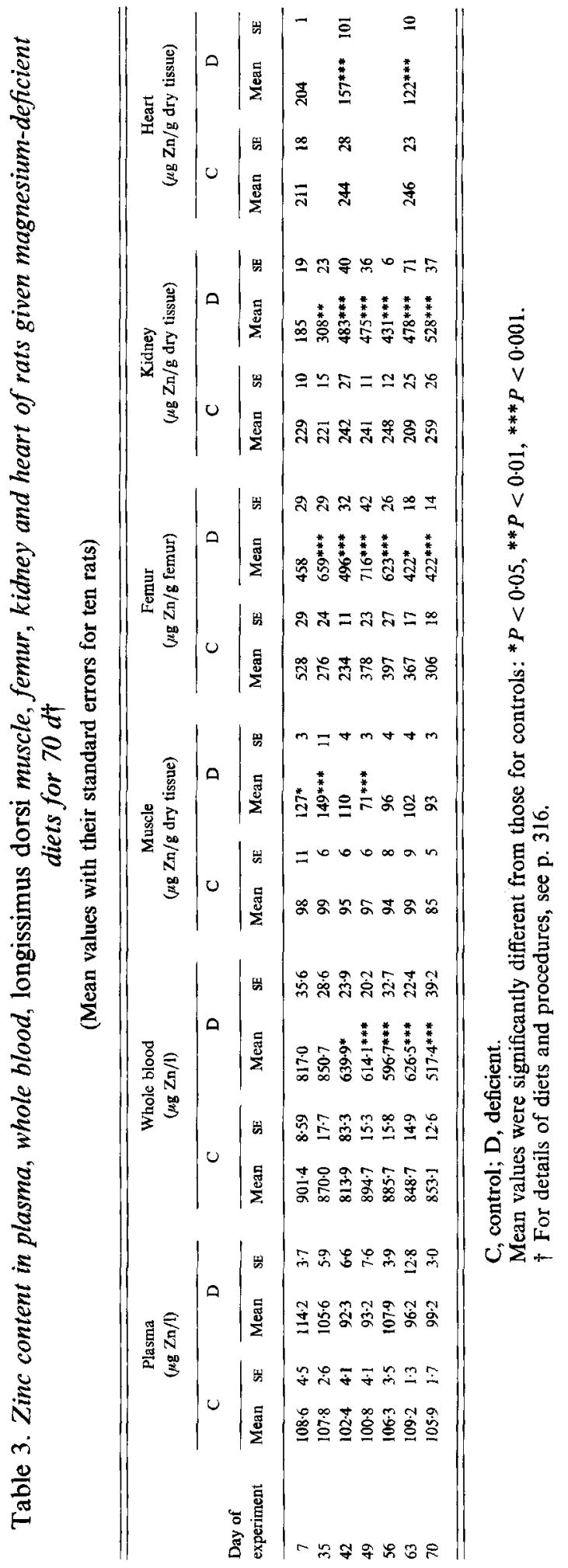


Table 4. Zinc content in brain of rats given magnesium-deficient diets for $70 d^{*}$

(Mean values with their standard errors for ten rats)

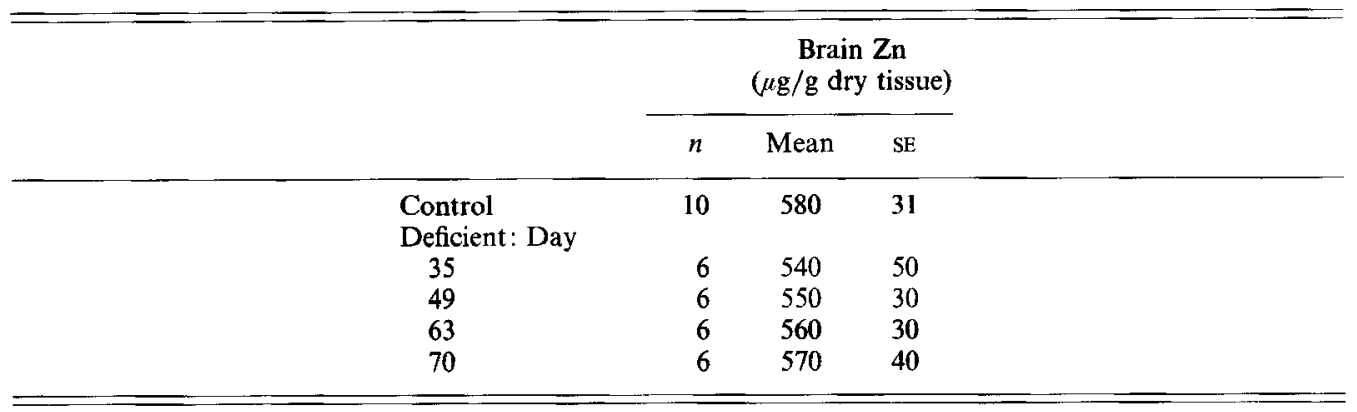

* For details of diets and procedures, see p. 316.

$\mathrm{Zn}$ excretion during the first week of study was significantly higher in the experimental group; however, urinary $\mathrm{Zn}$ concentration tended to decrease with time, and became significantly reduced in weeks 7 and 9 . After this time urinary $\mathrm{Zn}$ increased, reaching values slightly higher than those obtained for the controls (Table 1).

The Mg-deficient diet significantly increased $\mathrm{Zn}$ absorption (in $\mathrm{mg}$ ) from day 28 to day 35. As expected, apparent absorption of $\mathrm{Zn}$ and $\mathrm{Zn}$ balance showed the same trends as net $\mathrm{Zn}$ absorption (Table 2).

In whole blood, $\mathrm{Zn}$ concentration was significantly lower in the experimental group than in controls from day 42 to the end of the experimental period, and tended to decrease slightly as $\mathrm{Mg}$ deficiency became prolonged (Table 3). However, plasma $\mathrm{Zn}$ concentrations in the two groups did not differ significantly at any time-point, although it was slightly lower in Mg-deficient animals for most of the experimental period (Table 3).

$\mathrm{Zn}$ content in the longissimus dorsi muscle was greater for the $\mathrm{Mg}$-deficient group than for controls (Table 3 ) on days 7 and 35 ; after this time $\mathrm{Zn}$ content decreased gradually, becoming significantly lower for the experimental group on day 49 . Thereafter, muscle $\mathrm{Zn}$ concentration in $\mathrm{Mg}$-deficient rats increased, reaching values similar to those for the control group and remaining unchanged until the end of the experiment.

$\mathrm{Zn}$ content of the femur was significantly greater for $\mathrm{Mg}$-deficient rats than for controls from day 35 until the end of the experiment (Table 3).

In the kidney (Table 3 ), $\mathrm{Zn}$ content of dry tissue was significantly higher for $\mathrm{Mg}$ deficient rats from day 35 until the end of the experiment.

Heart tissues were studied on days 7, 42 and 63. Heart dry weight $(\mathrm{mg})$ was increased for Mg-deficient animals on day 42 (controls $141 \cdot 3$ (SE 5.2) v. experimental animals $192 \cdot 3$ (SE 6.4) $P<0.001$ ) and day 63 (controls 154.8 (SE 6.8) $v$. Mg-deficient rats $224 \cdot 1$ (SE 13.2); $P<0.001$ ). However, $\mathrm{Zn}$ concentration decreased with time. The differences between $\mathrm{Mg}$ deficient and control rats were significant from day 42 until the end of the experiment.

Brain $\mathrm{Zn}$ concentration in $\mathrm{Mg}$-deficient rats did not change significantly throughout the experiment (Table 4).

\section{DISCUSSION}

We studied the effects of $70 \mathrm{~d}$ on a Mg-deficient diet on the bioavailability of $\mathrm{Zn}$, and the $\mathrm{Zn}$ content of different organs and body compartments. $\mathrm{Mg}$ and $\mathrm{Zn}$ were analysed at weekly intervals except for weeks 2, 3 and 4, as earlier studies (Aranda et al. 1987, 1990) 
showed that under our experimental conditions (adult Wistar rats weighing $180 \mathrm{~g}$ at the start of the study) there were no relevant changes during this period.

Although the mechanism of $\mathrm{Zn}$ absorption has not been elucidated, kinetic studies have shown the involvement of both passive and carrier-mediated processes (Hempe \& Cousins, 1991), which may represent paracellular and transcellular transport pathways respectively (Hempe \& Cousins, 1992). Zn absorption by the carrier-mediated process is enhanced during periods of low $\mathrm{Zn}$ intake. In contrast, the diffusion component of $\mathrm{Zn}$ absorption is unaffected by $\mathrm{Zn}$ deficiency, and absorption via this process is proportional to luminal $\mathrm{Zn}$ concentration (Cousins \& Hempe, 1990). In feed-restricted control rats (Table 2), $\mathrm{Zn}$ absorption was reduced for most of the experiment, a finding which would not have been predicted by the previously mentioned results.

The findings in $\mathrm{Mg}$-deficient animals were similar: after week 5 , when $\mathbf{M g}$ deficiency reduced feed intake under our experimental conditions (Lerma et al. 1993), Zn absorption decreased. However, because the decline in absorption in Mg-deficient rats was much less evident than in controls, $\mathrm{Zn}$ absorption differed significantly between the two groups from week 5 until the end of the study (Table 2).

The smaller reduction in $\mathrm{Zn}$ absorption in $\mathrm{Mg}$-deficient animals may be related to changes in the permeability of intercellular junctions as a result of $\mathrm{Mg}$ depletion (Cassidy \& Tidball, 1967; Lemay \& Gascon-Barré, 1992). The paracellular pathway, a system of intestinal transport of great importance for many divalent cations, appears to be regulated by several nutrients such as $\mathrm{Ca}$ and $\mathrm{Mg}$ (Smith \& McAllan, 1966).

$\mathrm{Mg}$ deficiency may also modify $\mathrm{Zn}$ absorption indirectly by altering the availability of other divalent cations. Gunshin et al. (1991) noted the existence of competition among some divalent cations for common transporters.

The reduced feed intake in control rats between days 28 and 70 did not modify urinary excretion of $\mathrm{Zn}$ (Table 1), a finding that supports the assumption that under normal conditions the urinary excretion of $\mathrm{Zn}$ does not vary appreciably as a result of dietary composition, most $\mathrm{Zn}$ being eliminated in gastrointestinal secretions. This makes the intestinal pathway the major route of $\mathrm{Zn}$ excretion in rats (Disilvestro \& Cousins, 1983; Solomons, 1988).

Urinary excretion of $\mathrm{Zn}$ in $\mathrm{Mg}$-deficient animals was similar to that recorded for controls during most weeks of the study. The fluctuations may have been related to the marked increase in mineral content in the kidney (Table 3), which in turn may have impaired renal function.

Cation retention, calculated as $\mathrm{Zn}$ balance (Table 2), was probably regulated mainly by $\mathrm{Zn}$ absorption. This was borne out by our findings which showed $\mathrm{Zn}$ balance to follow a pattern similar to that of $\mathrm{Zn}$ absorption for both experimental and control animals.

We attributed the decrease in $\mathrm{Zn}$ concentration of whole blood from Mg-deficient animals (Table 3 ) to the decrease in intra-erythrocyte $\mathrm{Zn}$ levels, given that plasma $\mathrm{Zn}$ concentrations showed no significant fluctuations during the experimental period.

Decreased erythrocyte $\mathrm{Zn}$ content may have many causes. $\mathrm{Zn}$ may be shifted to the plasma compartment in order to maintain adequate plasma concentrations (Table 3 ) in the face of increasing $\mathrm{Zn}$ deposits in the bones and kidneys of $\mathrm{Mg}$-deficient animals (Table 3). Alternatively, alterations induced by $\mathbf{M g}$ deficiency in erythropoiesis may have been responsible for the loss of blood cell $\mathrm{Zn}$ (Kenney, 1981).

Recalling that $\mathrm{Zn}$ is involved in the stabilization of the erythrocyte membrane (Solomons, 1988; Cousins \& Hempe, 1990), the loss of erythrocyte $\mathrm{Zn}$ in Mg-deficient animals may contribute to the changes in fatty acid composition of the membrane (Aranda et al. 1989), possibly as a result of increased lipid peroxidation (Cousins \& Hempe, 1990).

The Mg-deficient diet increased muscle $\mathrm{Zn}$ concentration during the first 5 weeks of 
study, after which values declined and approached normality during week 6 (day 42), remaining unchanged thereafter until the end of the study (Table 3). These changes are suggestive of interactions between $\mathrm{Zn}^{+}$and $\mathrm{Mg}^{2+}$ in the skeletal muscle cell, which may account for the accumulation of $\mathrm{Zn}$ recorded during the first weeks of the experiment. The subsequent decline may have resulted from the mobilization of $\mathrm{Zn}$ by muscle tissue and erythrocytes in response to the accumulation of the cation in kidney and bone, in an effort to maintain adequate plasma levels. The $\mathrm{Mg}$-deficient diet significantly increased bone $\mathrm{Zn}$ content by day 35, despite the decline in feed intake (Table 3). However, Yasui et al. (1991) noted that feeding a diet with a low $\mathrm{Ca}$ and $\mathrm{Mg}$ content led to a loss of bone $\mathrm{Zn}$, which was much more marked when the diet was poor in $\mathrm{Ca}$ and $\mathrm{Mg}$ and rich in $\mathrm{Al}$. These findings suggest that the increase in bone deposition of $\mathrm{Zn}$ caused by $\mathrm{Mg}$ deficiency is influenced not only by interaction between the two ions, but also by other ions and/or metabolic alterations resulting from the lack of $\mathrm{Mg}$.

$\mathrm{Mg}$ is known to increase the solubility of oxalate, given the greater solubility of magnesium oxalate, and $\mathrm{Mg}$ deficiency leads to the appearance of $\mathrm{Ca}_{3}\left(\mathrm{PO}_{4}\right)_{2}$ and calcium oxalate deposits in the renal tubules (Bunce \& King, 1987).

The increase in renal $\mathrm{Zn}$ concentration in Mg-deficient rats (Table 3) points toward the participation of other divalent cations in the appearance of renal mineral deposits. From our findings we could not determine whether increased renal $\mathrm{Zn}$ content was a direct consequence of the $\mathrm{Mg}$ deficit or of changes in tubular $\mathrm{Ca}$ and $\mathrm{P}$ re-absorption.

Hypertrophy caused by the $\mathrm{Mg}$ deficit (Riggs et al. 1992) may account for the gradual increase in heart weight with time in rats given the $\mathrm{Mg}$-deficient diet. $\mathrm{Mg}$ deficiency also causes heart calcifications (Fischer \& Giroux, 1984; Wester, 1987; Lockard \& Bloom, 1991), which are apparently related to changes in coronary artery contractile response (Altura, 1979). In our Mg-deficient animals the declines in myocardial $\mathrm{Zn}$ concentration (Table 3) may have had the purpose of maintaining plasma $\mathrm{Zn}$ concentrations, or may have resulted from alterations (due to the $\mathrm{Mg}$ deficit) in the transport of this ion across the plasma membrane.

Despite the changes observed in various tissues from $\mathrm{Mg}$-deficient rats, brain concentrations of $\mathrm{Zn}$ (Table 4) did not vary significantly during the 7-week experimental period, suggesting that this cation is highly stable in brain tissue (Cousins \& Hempe, 1990).

The authors thank Ms Karen Shashok for translating the original manuscript into English.

\section{REFERENCES}

Altura, B. M. (1979). Sudden-death ischemic heart disease and dietary magnesium intake: is the target site coronary vascular smooth muscle? Medical Hypotheses 5, 843-848.

Aranda, P., Lerma, A. \& LLopis, J. (1989). Changes in erythrocyte membrane lipid structure during $\mathbf{M g}$ deficiency. Pflügers Archiv European Journal of Physiology 414, S13

Aranda, P., Lopez-Frias, M., Lopez-Jurado, M., LLopis, J., Rivero, M. \& Urbano, G. (1990). Recovery study in Mg-deficient rats given an organic source of Mg. Annals of Nutrition and Metabolism 34, $244-251$.

Aranda, P., Lopez-Jurado, M., LLopis, J., Mataix, F. J. \& Urbano, G. (1987). Nutritive utilization of Ca and Mg in $\mathrm{Mg}$ deficient rats. A recovery study. Journal of Nutritional Science and Vitaminology 33, 451-459.

Bunce, G. E. \& King, G. A. (1978). Isolation and partial characterization of kidney stone matrix induced by magnesium deficiency in the rat. Experimental Molecular Pathology 28, 322-325.

Cassidy, M. M. \& Tidball, C. S. (1967). Cellular mechanism of intestinal permeability: alterations produced by chelation depletion. Journal of Cell Biology 32, 685-698.

Cousins, R. J. \& Hempe, J. M. (1990). Zinc. In Present Knowledge in Nutrition, pp. 251-260 [M. L. Brown, editor]. Washington DC: International Life Sciences Institute, Nutrition Foundation.

Disilvestro, R. A. \& Cousins, R. J. (1983). Physiological ligands for copper and zinc. Annual Review of Nutrition 3, 261-288.

Fischer, P. W. F. \& Giroux, A. (1984). Effect of magnesium deficiency on mineral excretion and concentration in rat serum, heart and kidney. Nutrition Research 4, 51-57. 
Food and Agriculture Organization/World Health Organization (1966). Protein needs. Nutrition Meeting no. 37. Rome: WHO.

Forbes, R. M., Parker, H. M. \& Erdman, J. W. Jr (1984). Effects of dietary phytate, calcium and magnesium levels on zinc bioavailability to rats. Journal of Nutrition 114, 1421-1425.

Gunshin, H., Noguchi, T. \& Naito, H. (1991). Effect of calcium on the zinc uptake by brush border membrane vesicles isolated from the rat small intestine. Agricultural and Biological Chemistry 55, 2813-2816.

Hempe, J. M. \& Cousins, R. J. (1991). Cysteine-rich intestinal protein binds zinc during transmucosal zinc transport. Proceedings of the National Academy of Sciences USA 88, 9671-9674.

Hempe, J. M. \& Cousins, R. J. (1992). Cysteine-rich intestinal protein and intestinal metallothionein: An inverse relationship as a conceptual model for zinc absorption in rats. Journal of Nutrition 122, 89-95.

Hurley, L. S. \& Cosens, L. L. (1976). Magnesium, calcium and zinc levels of maternal and fetal tissues in magnesium deficient rats. Journal of Nutrition 103, 1261-1264.

Hurley, L. S. \& Swenerton, H. J. (1966). Congenital malformations resulting from zinc deficiency in rats. Proceedings of the Society for Experimental Biology and Medicine 123, 692-696.

Kenney, M. A. (1981). Blood cells in the Mg-deficient rats related to bone magnesium. Nutrition Reports International 23, 455-460.

Lemay, J. \& Gascon-Barré, M. (1992). Responsiveness of the intestinal 1,25-dihydroxyvitamin-D3 receptor to $\mathrm{Mg}$-depletion in the rat. Endocrinology 5, 2767-2777.

Lerma, A., Planells, E., Aranda, P. \& LLopis, J. (1993). Evolution of Mg deficiency in rats. Annals of Nutrition and Metabolism 37, 210-217.

Lockard, V. G. \& Bloom, S. (1991). Morphologic features and nuclide composition of infarction associated cardiac myocyte mineralization in humans. Journal of Pathology 139, 565-572.

Momcilovic, B., Belonje, B., Giroux, A. \& Shah, B. (1975). Total femur zinc as the parameter of choice for a zinc bioassay in rats. Nutrition Reports International 12, 197-203.

Riggs, J. E., Klinberg, W. G., Flink, E. B. \& Schochet, S. S. (1992). Cardioskeletal mitochondrial myopathy associated with chronic Mg deficiency. Neurology 42, 128-130.

Smith, R. H. \& McAllan, A. B. (1966). Binding of magnesium and calcium in the contents of the small intestine of the calf. British Journal of Nutrition 20, 703-718.

Solomons, W. N. (1988). Zinc and Copper. In Modern Nutrition in Health and Disease, pp. 238-261 [M. E. Shils and V. R. Young, editors]. Philadelphia: Lea and Febiger.

Wester, P. O. (1987). Magnesium. American Journal of Clinical Nutrition 45, 1305-1312.

Yasui, M., Ota, K. \& Garruto, R. M. (1991). Aluminium decreases the zinc concentration of soft tissues and bones of rats fed a low calcium-magnesium diet. Biological Trace Elements Research 31, 293-304. 